Article

\title{
The Utilisation of Migrant Capital to Access the Labour Market: The Case of Swedish Migrants in Helsinki
}

\author{
Östen Wahlbeck * and Sabina Fortelius \\ Swedish School of Social Science, University of Helsinki, 00170 Helsinki, Finland; E-Mails: osten.wahlbeck@helsinki.fi (O.W.), \\ sabina.fortelius@gmail.com (S.F.) \\ * Corresponding author
}

Submitted: 30 June 2019 | Accepted: 1 October 2019 | Published: 19 December 2019

\begin{abstract}
This article explains from a Bourdieusian perspective how migrants gain access to fields in which their resources are valued and their cultural and social capital can be mobilised. Interviews conducted among Swedish migrants in Helsinki (Helsingfors) illustrate how the migrants have been able to utilise various forms of capital to gain access to the local labour market. Knowledge of the Swedish language and society may constitute cultural capital, but only in specific occupations and social contexts. The article highlights the importance of access to social networks among Finnish spouses and friends in finding information about the jobs in which knowledge of the Swedish language and society is valued. The results indicate that the resources of migrants do not always constitute a valuable social capital, migrants also need to be able to mobilise their resources in a given social context. It is also argued that there may be specific forms of cultural and social capital that are only available to migrants as a consequence of their being migrants. This migrant capital consists of the various forms of capital that are connected to the migration process and are mobilisable by the migrants.
\end{abstract}

\section{Keywords}

Bourdieu; employment; Finland; labour market; migrant capital; social networks; Swedish language

\section{Issue}

This article is part of the issue "Social Inclusion beyond Borders: Utilization of Migrant Capital in Transnational and Diaspora Communities" edited by Sanna Saksela-Bergholm (University of Helsinki, Finland), Mari Toivanen (University of Helsinki, Finland) and Östen Wahlbeck (University of Helsinki, Finland).

(C) 2019 by the authors; licensee Cogitatio (Lisbon, Portugal). This article is licensed under a Creative Commons Attribution 4.0 International License (CC BY).

\section{Introduction}

This article presents results of an interview study conducted among Swedish migrants living in Helsinki (Helsingfors). The analysis of their experiences focuses on the mobilisation of cultural and social capital to gain access to the local labour market. Migrants moving from Sweden to Finland tend to be highly skilled, and may have both skills and access to various resources. Yet, a growing body of literature, including research in the Nordic countries, indicates that social integration remains a challenge even for highly skilled migrants (e.g., Habti \& Koikkalainen, 2014; Povrzanović Frykman \& Öhlander, 2018; Weinar \& Klekowski von Koppenfels, 2019). Furthermore, integration into the labour market tends to be a key integration challenge for migrants in Finland (Martikainen, Valtonen, \& Wahlbeck, 2012). Taking a Bourdieusian approach to capital theory, the article gives insights into processes of labour market integration and the mechanisms for mobilising migrant capital among Swedish migrants. Thus, the aim is to draw attention to both the agency of the migrants when they navigate a new labour market and the structural constraints of the fields in question (Bourdieu, 1986).

Finland is officially a bilingual country where both Finnish and Swedish are national languages, although Swedish is a minority language in practice. Swedish citizens are in a specific position as immigrants, because their first language is one of the national languages. For various historical reasons, Swedish may also constitute 
a form of cultural capital that is positively valued and may be locally associated with a good social status. In Helsinki, Swedish has historically been extensively used and there is a separate public education system and public institutions that according to the law should provide services in Swedish. Furthermore, private firms, especially those involved in trade with the Scandinavian countries, tend to value knowledge of the Swedish language. In terms of economic value, for instance, Sweden (together with Germany) is the most important export partner. Nevertheless, Swedish is not an asset in all situations and in all jobs in Finland. It is not easy for an immigrant to know where, how and in what social fields various language skills are valued. The need to acquire knowledge of the field is especially acute in the case of entry into the labour market, as the value of specific languages may vary a lot depending on the job in question. Various social networks may provide migrants with knowledge about the local labour market, and the results of our study point towards the importance of access to social networks among Finnish spouses and friends in finding information about the jobs in which knowledge of the Swedish language and society is valued.

\section{Migrant Capital}

Our analysis of migrant capital builds upon a Bourdieusian perspective on capital (Bourdieu, 1977, 1986) and is inspired by recent debates in the sociology of migration concerning the mobilisability of various forms of capital among migrants (Anthias, 2007; Cederberg, 2012; Erel, 2010; Erel \& Ryan, 2019; Ryan, Erel, \& D'Angelo, 2015; Wahlbeck, 2018). As Anthias (2007) points out, and Erel and Ryan (2019) outline more specifically, a Bourdieusian perspective on migrant capitals can be adopted to analyse how the mobilisation of resources depends on migrants' social positioning. Bourdieu generally distinguishes between economic, cultural and social capital, and one of the key characteristics of his theory is the convertibility and interplay of different sorts of capital. The concept of capital is one of Bourdieu's three main theoretical concepts, the other two being "habitus" and "field." Economic capital refers to the value of economic resources, such as money and material goods. Cultural capital, in turn, refers to a culturally specific "competence" (Bourdieu, 1986), whereas social capital is closely linked with social networks, and is defined as "the sum of the resources, actual or virtual, that accrue to an individual or a group by virtue of possessing a durable network of more or less institutionalized relationships of mutual acquaintance and recognition" (Bourdieu \& Wacquant, 1992, p. 119).

According to Bourdieu (1986), the various forms of capital always operate in a given social context, which he refers to as the field. Furthermore, social capital presupposes a continuous series of social exchanges. Thus, the value of social capital is never absolute and the possibility to mobilise a resource depends on the value it has in each field. Correspondingly, the dispositions and practices (i.e., habitus) of social actors change according to the shifting positions they take in the field and depend on how the valorisation of various forms of capital is (re)negotiated in the field (Bourdieu, 1977; Nowicka, 2015).

Migration includes movement from one social context to another: From a Bourdieusian perspective, migrants enter into new fields. The cultural and social capital that migrants possessed in the country of origin is seldom valued in the same way in the new social contexts in which they find themselves. However, it is important not to understand migrants' capital as a set of resources that migrants bring from their country of origin to the country of settlement that either fit or do not fit. As Erel (2010) argues, there is reason to use a Bourdieusian approach to question these so-called "rucksack approaches." She points out that migration often results in new ways of producing and re-producing (mobilising, enacting, validating) cultural capital that builds on, rather than simply mirror, power relations of either the country of origin or the country of migration. Thus, migrants should be seen as social actors who actively create new capital and validation mechanisms (Erel, 2010). To do this successfully, migrants need to navigate new social contexts and get information about the fields that are of significance for their social position. As discussed later in this article, the navigation may involve relations on multiple (micro, meso, and macro) levels of society, thus requiring a multilevel analysis of migrant capital (Erel \& Ryan, 2019).

Previous research on migrants' access to and trajectories in the labour market indicates that social capital is often a prerequisite for getting a job, whereas cultural capital may play a vital role in the establishment of new social networks (e.g., Camenisch \& Suter, 2019; del Rey, Rivera-Navarro, \& Paniagua, 2019; Ryan, Sales, Tilki, \& Siara, 2008; Thondhlana, Madziva, \& McGrath, 2016). Furthermore, the fact that an individual or a group has migrated may also provide the migrants in question with new skills and access to new resources. Personal experience of migration may be considered cultural capital, for example in specific occupations that value multicultural expertise. Furthermore, migration creates transnational social networks that migrants can utilise in various ways. These networks provide social capital that, for example, is useful in transnational entrepreneurship (Wahlbeck, 2018). We therefore argue in this article that there may be specific forms of cultural and social capital that are only available to migrants as a consequence of their being migrants. The various forms of capital that migrants can mobilise because of their personal involvement in migration are in this article described as "migrant capital." The fact that the migrants in our study came from Sweden may equip them with specific resources of value on the local labour market. Our analysis focuses on the strategies and agency of the migrants in finding a job in Helsinki, the aim being to provide information on the mobilisability of their migrant capital. 


\section{Methods}

This article reports results from semi-structured interviews with 30 Swedish citizens, conducted in Helsinki in 2011-2012. The general aims were to study migration patterns and experiences of social integration in a new social context. Finland and Sweden have a long common history of transnational migration, and Swedes with a significant Finnish ancestry or identity were excluded from the study. Hence, the sample comprised adult Swedish citizens in the age range between 20 and 55 , who had lived permanently for at least a year in Finland, but who were not Finnish citizens, did not have Finnish parents, were not born in Finland, and did not identify themselves as Finns. The interviewees had lived in Finland for up to 25 years, but the average was nine years. However, because of the transnational nature of the migration patterns it was often difficult to calculate the exact length of stay in Finland. Many had moved multiple times back and forth between the two countries, and the move to Finland tended to be a gradual process (Wahlbeck, 2015a). The interviews included an almost equal number of men and women (14 men and 16 women). Interviewees complying with the sample criteria were found through various informal channels combined with snowball sampling (Fortelius, 2014; Wahlbeck, 2015b).

The interviews were carried out by both authors. They were conducted in Swedish and the length was between one and two hours. All the interviews were fully transcribed. A comprehensive content analysis of the transcriptions was facilitated by the use of a computer program for qualitative analysis guided by the methodology of grounded theory (Atlas-ti). The quotations from the interviews cited in this article were translated from Swedish into English by the authors, and the names of the interviewees are pseudonyms.

The interviews were semi-structured and focused on migration and integration experiences. Among the topics were the reasons and motivations for the migration decisions, and detailed questions were asked about the social ties that facilitated migration and integration. The methods, the data and some of the results concerning migration patterns and social integration have been presented in previous publications and unpublished reports of this research project (Fortelius, 2014; Wahlbeck, 2015a, 2015b). This article builds upon the results of the project to provide a unique analysis of the transcribed interviews from the perspective of migrant capital theory.

\section{Swedish Migration to Finland}

The migration of Swedish citizens from Sweden to Finland has not followed the typical pattern of migration between these two countries, in that the major migration flow has been that of Finns moving to Sweden. Labour migration from Finland to Sweden is among the largest labour migration flows in post-war Europe. It was facilitated by Nordic agreements in the 1950s on the freedom of movement, equal social rights and a common labour market. These agreements apply to citizens of all Nordic countries (Denmark, Finland, Iceland, Norway and Sweden), but the free movement was initially mostly utilised by Finns. Swedish population statistics record 530,000 official migrants from Finland to Sweden in the period 1945-1999, most of them during the 1960s and 1970s. This mass migration was followed by a return migration of more than half of the Finnish migrants: 300,000 people officially moved in the other direction during the same period of time. Return migration and repeated migration became increasingly common and the migrants developed extensive transnational social ties and networks involving both countries (Korkiasaari \& Tarkiainen, 2000; Wahlbeck, 2015a).

Until recently, it was predominantly Finnish citizens that moved in both directions between Finland and Sweden. Thus, research on the migration of Finns is extensive, whereas very few studies have been conducted on Swedes moving to Finland. However, population statistics clearly show that the number of Swedish citizens (especially males) moving to Finland has steadily increased since the late 1970s. Our study explicitly focused on Swedish migrants who did not have a previous connection to Finland, the aim being to study the migration motivations of this new group of migrants. The significant explanation of the migration was that the Swedes had moved to Finland with, or because of, a Finnish partner. Mixed families consisting of Finnish and Swedish citizens are very common in both countries, the family combination of a Swedish man and a Finnish woman being more common than vice versa (Wahlbeck, 2015a, 2015b). Consequently, there is an overrepresentation of men among Swedish migrants in Finland: At the time of this study, $63 \%$ of Swedish citizens in Helsinki were men (Wahlbeck, 2015b, pp. 56-62). Nevertheless, there are both men and women who originally arrived as single young migrants with the initial intention to stay for a short period of time, but ending up staying for a longer time, which is similar to the migration trajectories found among Swedish female migrants in the United States (Lundström, 2014) and young Swedes in Norway (Tolgensbakk, 2015).

Helsinki, the capital of Finland, has been the major destination for Swedish migrants moving to Finland in recent years. Excluding people with dual Finnish citizenship, the number of Swedish citizens in Helsinki in 2010 was 1278 people, comprising 803 men and 475 women (Statistics Finland, 2019). The city is a suitable location in which to study integration into a local labour market, being geographically situated relatively far from Sweden (i.e., frequent commuting to Sweden, which can be found in some parts of Finland, is out of the question). Helsinki provides good employment opportunities, at least in comparison to other parts of Finland where there are mostly relatively high rates of unemployment, especially among the foreign-born population. Of signif- 
icance for the labour market integration of Swedish migrants is the fact that Finland has a sizeable national minority of Swedish-speaking Finns living in the coastal regions. Although the proportion of Swedish speakers has steadily diminished in Helsinki, the city still has a relatively large and significant Swedish-speaking minority (Kraus, 2011). In 2018, about $6 \%$ of the population of Helsinki (36,000 people) indicated Swedish as their native language, whereas $78 \%$ indicated Finnish (Statistics Finland, 2019). There are both private and public institutions and workplaces in Helsinki where Swedish is spoken. However, there is a recognisable difference in accent between the Swedish spoken in Finland and that spoken in Sweden, and in some situations (and jobs) this may play a role in the valuation of language skills.

\section{The Position of the Swedish Migrants in the Labour Market}

As mentioned above, the majority of the interviewees had moved to Finland primarily because of a Finnish spouse, and rarely because of a job. Only a few had a job in Finland when they moved, and even fewer could be characterised as "intra-corporate expatriates" (Camenisch \& Suter, 2019), who were posted to Finland by their companies for a certain period of time. Therefore, most of the interviewees had actively to navigate the local labour market to find a job after arriving in the country.

All the interviewees were native speakers of Swedish, with limited or non-existent skills in Finnish. Not surprisingly, they eventually found jobs that did not require a good knowledge of Finnish. Initial occupations tended to have low requirements in terms of skills or assets, so-called entry-level occupations, or the specific skills required corresponded to the national background of the employee, so-called ethno-specific occupations (Fortelius, 2014). This pattern of employment in entrylevel and ethno-specific jobs is common among recently arrived migrants in Finland, but the types of occupations available to the Swedes still differed substantially from those available to other migrant groups. There are entry-level jobs in Helsinki that require knowledge of Swedish. Furthermore, because good knowledge of Swedish is relatively rare among local jobseekers, many of the interviewees found employment in specific sectors of the labour market. Examples of such workplaces include Swedish-language day care for children, schools, care units for Swedish-speaking elderly people, cultural institutions, university departments, and some Swedishowned companies, especially in the financial sector. As the following quotations indicate, there is a large demand for staff in the Swedish-language day-care and public education system:

There are e-mail addresses for all Swedish-language schools and day-care centres in the Helsinki region. So, I simply e-mailed all of them...It only took two hours for the [current workplace] to call me, and they asked me to come for an interview.... started work three days later.... cannot remember how many of them called me. You know, as I said, I sent [an application] to all Swedish-speaking places, and I do not know if it was like, I think it was thirteen that called. (Peter, aged 28, 3 years in Finland)

Another interviewee, Johan, had less luck with his applications and instead found part-time employment in a Swedish-language afternoon day-care centre. The social capital of the interviewees assumed significance when other forms of capital remained unrecognised. Both Peter and Johan had job contracts that only covered the school year, due to the lack of the formal education required. It was a common pattern among the interviewees to start their first job in Finland on a short-term contract, which was then extended or led to other longerterm positions. Johan continued his struggle to gain access to his preferred field and to utilise competences and job experiences he had gained in Sweden. In the meantime, he utilised his social capital to find a job in children's day-care. These centres have a predominantly female workforce, thus it could be an advantage to be a male applicant:

And then the [other job] I got through my roommate. [The roommate] said they needed people so then [I] e-mailed and I told them I knew [roommate] and so on, and then I got it. So, actually I have not got a single job that I have applied for, instead I have got jobs through contacts. Exclusively. (Johan, aged 25, 1 year in Finland)

It seemed to be an additional asset, or even a requirement, in some occupations to be from Sweden. It was not only an excellent knowledge of Swedish that was an asset in these ethno-specific occupations, but also a Swedish accent and cultural knowledge of the country. Examples of such employers include private firms offering language courses, interpretation services and general orientation training for cultivating business contacts with Sweden. Several interviewees worked-either selfemployed or in the private sector-as translators or as teachers of the Swedish language:

I had never worked as a teacher before. [The advertisement] said that, ok, a teaching degree is positive, but it wasn't a requirement. The requirement was that you should come from Sweden. And when I got to the interview it was like, no, it's no problem that you don't have the education, it's the social competence [that matters]. (Mikael, aged 30, 1 year in Finland)

As shown in the above quotation, not only did the company want their employees to be fluent in Swedish as a language, it also wanted someone with knowledge of cultural norms and other aspects of Swedish society. The 
teacher was expected to pass on his knowledge not only of the Swedish language per se, but also of aspects of Swedish culture:

If nothing else...you have certain knowledge that other Swedish speakers here do not have. You have contacts with Sweden in a totally different way, so for some companies it can be very good....There are very many big enterprises nowadays that are FinnishSwedish or Nordic, yes [cultural knowledge] can be good. (Mikael, aged 30, 1 year in Finland)

In this case, the interviewee succeeded in finding a job in which his specific cultural capital was not only valued but required. He thus managed to utilise his cultural capital, which in his case was also connected to his educational background. In other cases, the Swedish migrants had to find jobs in areas that did not correspond to their educational background. According to Erel (2010, p. 649), migrants may redefine and recreate forms of migrated cultural capital in order to validate the capital in their countries of residence. Thus, building on the analytical approach outlined by Erel (2010, p. 651), one can argue that the interviewees were able to mobilise their background as Swedish migrants into cultural capital that helped them to gain employment (Fortelius, 2014, pp. 77-78). This capital can be perceived as migrant capital, which they would not have had if they had not moved from Sweden to Finland. Thus, as Swedish migrants the interviewees possessed "embodied cultural capital" (Bourdieu, 1986) that was of value on the local labour market in Helsinki. Karin, who had had several different jobs, explained the value of her nationality as follows:

Yes, [to be from Sweden] has always been a benefit for me in the jobs I have had. Yes. I think, as a foreigner in Finland, or if you don't have Finnish as your native language, the jobs you get, or are involved in, easily can depend on your nationality.... m managed to get jobs as a freelance teacher in Swedish, in private language schools. And there were rather many Swedes that got them, that had these jobs. And the job was fun, so I did that for many years. (Karin, aged 45, 16 years in Finland)

As the above examples indicate, some of the interviewees found a job relatively easily. It seems that some of the skills and resources of the Swedish migrants were both recognised and valued in specific fields of the labour market in Helsinki. Although formal education obtained in Sweden could in some cases be devalued or considered insignificant, the migrants usually could rely on other forms of cultural and social capital. The relatively good employment situation is confirmed in official statistics showing a lower level of unemployment among Swedish immigrants than among other immigrant groups in Helsinki, and a level that is comparable to that among Finnish-born Finnish citizens (Saukkonen, 2016).
Some of the interviewees managed to find employment that corresponded to their work experience in Sweden, whereas others were able to enter new occupations because of how their cultural and social capital as Swedish migrants was valued. Thus, the migrant capital of the interviewees was recognised and they were able to mobilise their resources into cultural and social capital in the local labour market. Our results also indicate that, among our interviewees, migrant capital could be utilised to differentiate them from other Swedish speakers in Finland and thus to strengthen their position in the labour market. Several interviewees also stressed their networks in Sweden, which they used in their everyday work:

If it was not for me, there would be significantly less contact with Sweden, I presume. People would first and foremost look for somebody here [in Finland]. And I also support that, but sometimes I think there is a purpose in having like a Swedish-speaking Swedish citizen. But yes, I am the one who deals with $90 \%$ of the cases in which Swedes are involved. (Erik, aged 35, 12 years in Finland)

\section{Navigating the Field of the Labour Market}

As the results outlined above indicate, many of the migrants in our study were able to navigate new fields, and to find positions in specific fields where they managed to achieve a positive valuation of their capitals. Our findings also imply that it is not enough to possess resources, they also need to be mobilisable to be considered capital of value. The value of the skills and resources of social actors are never absolute and their "mobilisability" largely depends on the social context of the field (e.g., Anthias, 2007; Wahlbeck, 2018).

In this study, the importance of the social context is exemplified by the fact that the Swedish migrants needed to get information about the labour market to find the right jobs to apply for. From a Bourdieusian perspective, exchanges in social networks can generate social capital, which in turn can be defined as useful connections through which to gain access to the field or to get useful information about the rules of the field (Bourdieu \& Wacquant, 1992). Thus, the migrants needed to get information about the specific local jobs and occupations in which their assets could be of value. Not surprisingly, the interviewees strongly stressed the importance of having the right contacts:

Forget about this with education! Because I was very afraid of that at the beginning when I heard that, shit, like, everyone here has a Master's degree and you won't get a job unless you have like seven degrees and have all your papers....But this is not the case, it's contacts, contacts, contacts and personality. (Erik, aged 35, 12 years in Finland) 
As the above quotation indicates, social capital is generated by "contacts." Since most of the interviewees had a Finnish partner, this partner became an important source of social contacts. The interviews revealed that this was the case both for men and for women. In many instances the partner was the first and only contact the interviewee had had with Finland before moving to the country. The partner also provided information about local society, especially immediately after migration when the interviewee had not yet established local social ties of his or her own. For example, Peter (aged 28, 3 years in Finland) explained that the process of integration "was through my wife....She told [me] what there is, like different ways of getting into society here."

The partners' social contacts, mostly in the form of friends and family of the partner, were part of broader social networks that provided the migrant with further possibilities to obtain information and navigate the labour market. Swedish migrants affiliated with a Finnish family have, upon arrival, access to well-established social networks upon which they can rely during the initial period in Finland. As the following quotation testifies, partners provided the first local network that the interviewees were able to build upon: "With each passing year, you build on your network through various channels. But in the beginning, I was very very strongly [connected] through my husband" (Eva, aged 38, 8 years in Finland). As a consequence of migration, the social roles played by partners may significantly change depending on the types of social connections that the partners have in the new society of settlement. These changes may involve new internal and external family roles, as described in many studies on changing family dynamics in migration (e.g., Juozeliūnienè \& Budginaitè, 2016; Ryan, 2019; Ryan \& Mulholland, 2014; Wahlbeck, 2015a). Thus, as Erel and Ryan (2019) point out, not only are individual micro-level migrant strategies situated within wider macro contexts, they are also experienced through and facilitated by the meso-level of families and social networks.

In this study, the partners played a role in providing general information about navigating the labour market, but in the end the outcome, in other words getting or failing to get the job, depended on the valuation of the assets of the applicants themselves. Nevertheless, the social networks of the Finnish partner directed the navigation of the field in different directions depending on the social role and connections that the partner possessed. This may also limit the contacts to specific social networks. In cases where the migrants did not have a Finnish partner to rely on, the process of navigating the field of the labour market became much more difficult. Moreover, the type of social connections of the partner varied depending on whether or not the partner was a member of the local Swedish-speaking community. Johan, for example, who had no contacts with Swedishspeaking Finns, experienced many problems finding a job corresponding to his education:
Johan: But I don't know, it may be that I have not [found any job] because I don't speak Finnish, I guess that could be the reason. It may be that they did not even understand my [job] application, because it was not in Finnish, I sent it in English and Swedish.

Sabina: So, you don't have anybody among your acquaintances with contacts to follow up? Within your [professional] field?

Johan: I have tried to find out if there are, but it seems not....The Finnish-speakers I know have had some information about job vacancies, but they have always been for Finnish speakers, so that has not been of any help. (Johan, aged 25, 1 year in Finland)

As described above, many interviewees experienced problems finding a job because of their lack of knowledge of Finnish. As a consequence, the role of the small Swedish-speaking labour market is easily accentuated among Swedish migrants, who actively use this specific field as a gateway to employment (Fortelius, 2014; Wahlbeck, 2015b). The interviews revealed that social contacts with Swedish-speaking Finns had played an instrumental role in providing information about workplaces in which knowing Swedish would be considered an asset and a lack of knowledge of Finnish would not be a hindrance to employment.

Thus, although social networks play a decisive role in terms of obtaining information and navigating the labour market in Helsinki, the challenge migrants have to overcome is that different networks provide different opportunities in this respect. Thus, migrants need to "develop strategies to access social capital (through networks) and overcome de-skilling by building new cultural capital (credentials) in the destination society" (Erel \& Ryan, 2019, p. 259). The strategies that many migrants adopted was to access the social networks of the Swedish-speaking minority and through these networks find the fields in which knowledge of Swedish was valued. As one interviewee explained, when asked what advice should be given to newly arrived Swedes, it was necessary to find the right networks to find a job in Helsinki:

In this case, first try to sort out the terrain of the Swedish-speaking Finns...just to get your foot in the door somewhere, to get into the labour market in some way. In this case I would suggest taking the easy way, maybe it's not even your dream job, but you still kind of get your foot in, and you become part of the system and things start to roll. And at the same time, they will perhaps offer some further education on something and you can kind of extend your network. I mean, I would never have moved from [an occupation] into [another occupation] in Sweden. But you have to say thank you and carry on. That is what I did, and I think this makes you learn a lot, and about how the system basically works. (Anna, aged 40, 9 years in Finland) 
As the above quotation indicates, the community of the Swedish-speaking minority in Helsinki may provide a useful network via which to navigate the labour market. The social ties of the community are strong, and members of the community have information about the jobs in which knowing Swedish is a valued asset. Thus, the Swedishspeaking community was something of a buffer-zone, a touchdown before stepping out into the larger society or labour market (Fortelius, 2014, p. 58).

There was a tendency among the interviewees to become more and more socially involved in the networks of the local Swedish-speaking minority, especially if the spouse or partner belonged to this minority (Wahlbeck, 2015b, pp. 136-166). These social networks were established through personal contacts both at the workplace and in the course of various spare-time activities of the interviewees. Among the families with children, for example, many of the female interviewees (but, interestingly, none of the males) mentioned that social contacts were often established as a consequence of taking part in activities at their children's school. Karin (aged 47, 10 years in Finland) explained that many of her local networks developed through contacts established in connection with the Swedish-language school that her children attended: "so, there are plenty of parents of my children's school friends." In this way, the micro-level social relationships within families contributed to the social networks on the meso-level, which tended to be differentiated by language and concentrated in the networks of the local Swedish-speaking minority. As Erel and Ryan (2019) point out, "child-based sociality" may open up networking possibilities for migrants, but the availability of these types of social network also depends on whether the "migrants' life course is in tune with normative meso-level and macro-level socio-structures" (Erel \& Ryan, 2019, p. 259). The normative structures in question may relate to age or social class, for example. The results of our study indicate that this may not only be limited to the age and social class of the migrants, but also extends to the age and social class of the spouse of the migrant, since many networks were accessed with the help of the spouse. In general, the results of our study indicate that there was a wide variation among the interviewees concerning access to and participation in local social networks of potential labour-market relevance.

Although the Swedish-speaking minority provided useful information about available jobs, as a relatively small minority its social networks are limited. Thus, the migrants also strived to gain access to other networks and to a broader labour market than the one offered by the Swedish speakers. Many interviewees perceived the Finnish-speaking society as the final goal of integration, and some even expressed anxiety about the potential limitations of social affiliation with a small national minority. However, lacking knowledge of Finnish was a challenge that both limited social contact with the Finnish-speaking majority and made it difficult to compete for jobs in the general labour market in Helsinki.
Eva expressed this limitation strongly: "It's a never ending scourge, because there are so so many things I could do in Sweden...that I can not do here... because I can only work in English or Swedish." In an attempt to overcome this limitation, most of the interviewees worked hard at learning Finnish, but found it challenging to learn enough to be able to compete for jobs that required a working knowledge of the language. The mobilisability of the cultural capital of the Swedish migrants was limited to specific fields of the local labour market, which highlights the fact that the valuation of capital is connected to and limited by specific social contexts (cf. Anthias, 2007). Yet, in some fields the capital of the migrants is highly valued and the migrants actively develop strategies to identify and navigate these particular fields.

\section{Conclusion}

Our interview study revealed how Swedish migrants with no previous connection to Finland gained access to the local labour market in Helsinki. Labour market integration constitutes a concrete example of the processes whereby migrants enter a new "field" (Bourdieu, 1986). The results confirm that access to social networks is decisive for gaining access to the labour market. The interviewees stressed the importance of contacts in getting information about jobs and how to navigate the local labour market in Helsinki. Thus, access to the specific fields in which the cultural or social capital of the migrants would be highly valued was crucial. Information about and access to jobs in which knowledge of Swedish was an asset turned out to be critical in this respect. Thus, contacts with members of the Swedish-speaking minority in Helsinki turned out to be especially valuable in finding these specific jobs.

Most of the interviewees had a Finnish spouse, since the spouse often was the reason for moving to Finland. The results indicate that the social networks of the Finnish spouse were decisive in terms of the types of jobs the migrants found out about. In practice, the native language of the spouse-the Finnish majority language or the Swedish minority language-tended to have a major impact on the social networks that the migrant would learn about and would be able to access. The social networks of the Finnish spouse were especially relevant to the migrants during the period immediately after their arrival in Finland, but after some time they became less dependent on their spouses and usually managed to gain a foothold in the general labour market. Eventually, their skills and assets could be highly valued on the local labour market.

Thus, the Swedish migrants we interviewed were relatively successful in entering the local labour market. However, the field in question makes a difference, as it was clearly easier to get some jobs than other jobs. The migrants were able to find jobs in occupations in which knowledge of Swedish language and culture was considered a form of capital. Other occupations were more dif- 
ficult to access and demanded social capital to compensate for the lack of sufficient knowledge of the Finnish language. Our results indicate that the resources that $\mathrm{mi}$ grants possess also need to be mobilisable in the fields that are of significance for the social position of the migrants (cf. Anthias, 2007; Wahlbeck, 2018). Resources are not simply carried by migrants into a new social field, the value of a resource depending both on how migrants are able actively to validate the capital and the significance of power relations and social structures in this process. Thus, our results support the Bourdieusian approach to migrant capital, in which migrants are seen as social actors who actively create new capital and validation mechanisms (Erel, 2010).

Furthermore, the process of validating capital is a multi-level process, involving both individual agency on the micro-level, the utilisation of family networks on the meso-level, and navigating the opportunity structure provided on the macro level of economic structures (Erel \& Ryan, 2019). Thus, our multi-level analysis of the strategies of the Swedish migrants indicates that individual agency is needed to navigate the fields in which migrant capital can be mobilised. For example, knowledge of Swedish language and culture constitutes embodied cultural capital, but only in specific jobs and occupations. On the meso level, the social networks of families and the local Swedish-speaking minority can provide useful information about job opportunities, but access to these networks may depend on the age of the migrant and the social ties of the Finnish spouse of the migrant, for example. Finally, valuation of the migrant capital in question may depend on economic and political changes on the macro level, such as the extent of trade and business contacts between Finland and Sweden.

A Bourdieusian perspective on capital is useful in that it highlights the dynamic processes involved when migrants validate various forms of capital in a new field. The perspective captures the processes and variations in the mobilisability of capital that migrants experience. In this article we have used the experiences of Swedish migrants on a specific local labour market to describe the utilisation of various forms of capital, which exemplifies general processes of social inclusion in a new field. Although migrants may find it a challenge to utilise their resources in a new field, they are also able to generate and mobilise new forms of cultural and social capital. These capitals constitute a specific migrant capital that is mobilisable only because the migrants have moved to a new field. Thus, the concept of migrant capital captures both the agency of the migrants as well as the structural constraints of the field in which various forms of capital are generated and utilised.

\section{Acknowledgments}

The research has received funding from the Society of Swedish Literature in Finland (Svenska litteratursällskapet i Finland).

\section{Conflict of Interests}

The authors declare no conflict of interests.

\section{References}

Anthias, F. (2007). Ethnic ties: Social capital and the question of mobilisability. The Sociological Review, 55(4), 788-805. https://doi.org/10.1111/j. 1467-954X.2007.00752.x

Bourdieu, P. (1977). Outline of a theory of practice. Cambridge: Cambridge University Press.

Bourdieu, P. (1986). The forms of capital. In J. G. Richardson (Ed.), Handbook of theory and research for the sociology of education (pp. 241-258). New York, NY: Greenwood Press.

Bourdieu, P., \& Wacquant, L. (1992). An invitation to reflexive sociology. Chicago, IL: University of Chicago Press.

Camenisch, A., \& Suter, B. (2019). European migrant professionals in Chinese global cities: A diversified labour market integration. International Migration, 57(3), 208-221. https://doi.org/10.1111/imig.12585

Cederberg, M. (2012). Migrant networks and beyond: Exploring the value of the notion of social capital for making sense of ethnic inequalities. Acta Sociologica, 55(1), 59-72. https://doi.org/10.1177/ 0001699311427746

del Rey, A., Rivera-Navarro, J., \& Paniagua, T. (2019). "Migrant capital" and domestic work: Labour trajectories of immigrant women in Spain. International Migration, 57(3), 155-170. https://doi.org/10.1111/ imig. 12573

Erel, U. (2010). Migrating cultural capital: Bourdieu in migration studies. Sociology, 44(4), 642-660. https:// doi.org/10.1177/0038038510369363

Erel, U., \& Ryan, L. (2019). Migrant capitals: Proposing a multi-level spatio-temporal analytical framework. Sociology, 53(2), 246-263. https://doi.org/10.1177/ 0038038518785298

Fortelius, S. (2014). Mobilised resources or unrecognised assets? A case study of Swedish citizens' paths to employment in Helsinki (Unpublished Masters dissertation). Faculty of Social Sciences, University of Helsinki, Helsinki, Finland. Retrieved from https:// helda.helsinki.fi/handle/10138/228350

Habti, D., \& Koikkalainen, S. (2014). International highly skilled migration. The case of Finland: An introduction. Journal of Finnish Studies, 17(1/2), 3-17.

Juozeliūnienè, I., \& Budginaitè, I. (2016). Global migration and family change in the Baltic Sea region. Journal of Comparative Family Studies, 47(1), 65-86. https://doi.org/10.3138/jcfs.47.1.65

Korkiasaari, J., \& Tarkiainen, K. (2000). Suomalaiset Ruotsissa [Finns in Sweden]. Turku: Siirtolaisuusinstituutti.

Kraus, P. (2011). The multilingual city: The cases of Helsinki and Barcelona. Nordic Journal of Migra- 
tion Research, 1(1), 25-36. https://doi.org/10.2478/ v10202-011-0004-2

Lundström, C. (2014). White migrations: Gender, whiteness and privilege in transnational migration. London: Palgrave Macmillan.

Martikainen, T., Valtonen, K., \& Wahlbeck, Ö. (2012). The social integration of immigrants in Finland. In J. Frideres \& J. Biles (Eds.), International perspectives: Integration and inclusion (pp. 127-146). Montreal: McGill-Queen's University Press.

Nowicka, M. (2015). Habitus: Its transformation and transfer through cultural encounters in migration. In C. Costa \& M. Murphy (Eds.), Bourdieu, habitus and social research (pp. 93-110). London: Palgrave Macmillan.

Povrzanović Frykman, M., \& Öhlander, M. (Eds.). (2018). Högutbildade migranter i Sverige [Highly skilled migrants in Sweden]. Lund: Arkiv.

Ryan, L. (2019). Narratives of settling in contexts of mobility: A comparative analysis of Irish and Polish highly qualified women migrants in London. International Migration, 57(3), 177-191. https://doi.org/10.1111/ imig. 12493

Ryan, L., Erel, U., \& D’Angelo, A. (Eds.). (2015). Migrant capital: Networks, identities and strategies. London: Palgrave Macmillan.

Ryan, L., \& Mulholland, J. (2014). 'Wives are the route to social life': An analysis of family life and networking amongst highly skilled migrants in London. Sociology, 48(2), 251-267. https://doi.org/10.1177/ 0038038512475109

Ryan, L., Sales, R., Tilki, M., \& Siara, B. (2008). Social networks, social support and social capital: The experiences of recent Polish migrants in London. Sociology, 42(4), 672-690. https://doi.org/10.1177/ 0038038508091622
Saukkonen, P. (2016). Maahanmuuttajien työllistyminen Helsingissä [The employment of immigrants in Helsinki]. Kvartti, 4. Retrieved from https:// www.kvartti.fi/fi/artikkelit/maahanmuuttajientyollistyminen-helsingissa

Statistics Finland. (2019). StatFin-Online service. Statistics Finland. Retrieved from http://www.stat.fi

Thondhlana, J., Madziva, R., \& McGrath, S. (2016). Negotiating employability: Migrant capitals and networking strategies for Zimbabwean highly skilled migrants in the UK. The Sociological Review, 64(3), 575-592. https://doi.org/10.1111/1467-954X.12373

Tolgensbakk, I. (2015). Partysvensker; Go hard! En narratologisk studie av unge svenske arbeidsmigranters nærvær i Oslo [Party Swedes: Go hard! A narrative study of young Swedish labour migrants' presence in Oslo] (Unpublished Doctoral dissertation). Faculty of Humanities, University of Oslo, Oslo, Norway. Retrieved from http://urn.nb.no/URN:NBN:no-47783

Wahlbeck, Ö. (2015a). The Finnish and Swedish migration dynamics and transnational social spaces. Mobilities, 10(1), 100-118. https://doi.org/10.1080/ 17450101.2013 .849488

Wahlbeck, Ö. (2015b). Inflyttad från Sverige: En studie av rikssvenska erfarenheter $i$ Helsingfors [Immigrated from Sweden: A study of Swedish experiences in Helsinki]. Hedemora: Gidlunds.

Wahlbeck, Ö. (2018). The transferability and mobilisability of transnational resources: The case of Turkish entrepreneurs in Finland. Nordic Journal of Migration Research, 8(4), 237-244. https://doi.org/10. 2478/njmr-2018-0027

Weinar, A., \& Klekowski von Koppenfels, A. (2019). Migration, mobility, integration, segregation-Migrations within the Global North. International Migration, 57(3), 171-176. https://doi.org/10.1111/imig.12501

\section{About the Authors}
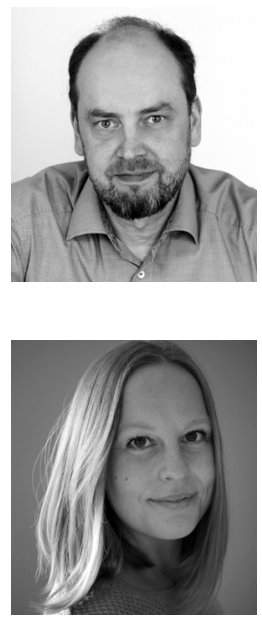

Östen Wahlbeck is Senior Lecturer in Social Sciences at the University of Helsinki, Adjunct Professor of Sociology at the University of Tampere, and Professor II in Human Rights and Multiculturalism at the University of South-Eastern Norway. He holds a PhD in Ethnic Relations from the University of Warwick (1997). He has published widely in the field of international migration and ethnic relations. His research interests include integration and asylum policies, transnationalism, multiculturalism and minority rights.

Sabina Fortelius majored in Sociology from the Master's degree programme in Ethnic Relations, Cultural Diversity and Integration at the University of Helsinki. She has since worked as a Project Leader, consulting organisations on how to promote diversity and inclusion and implement strategies for increased accessibility. Her academic interest lies in the field of migration and integration, with a special interest in labour market integration. 